\title{
Clinical and molecular features of an infant patient affected by Leigh Disease associated to m.14459G > A mitochondrial DNA mutation: a case report
}

\author{
Dario Ronchi ${ }^{1}$, Alessandra Cosi ${ }^{1}$, Davide Tonduti ${ }^{2}$, Simona Orcesi ${ }^{2}$, Andreina Bordoni ${ }^{1}$, Francesco Fortunato ${ }^{1}$, \\ Mafalda Rizzuti ${ }^{1}$, Monica Sciacco ${ }^{1}$, Martina Collotta', Sophie Cagdas ${ }^{3}$, Giuseppe Capovilla ${ }^{3}$, Maurizio Moggio ${ }^{1}$, \\ Angela Berardinelli ${ }^{2}$, Pierangelo Veggiotti ${ }^{2}$ and Giacomo P Comi ${ }^{*}$
}

\begin{abstract}
Background: Leigh Syndrome (LS) is a severe neurodegenerative disorder characterized by bilateral symmetrical necrotic lesions in the basal ganglia and brainstem. Onset is in early infancy and prognosis is poor. Causative mutations have been disclosed in mitochondrial DNA and nuclear genes affecting respiratory chain subunits and assembly factors.

Case presentation: Here we report the clinical and molecular features of a 15-month-old female LS patient. Direct sequencing of her muscle-derived mtDNA revealed the presence of two apparently homoplasmic variants: the novel m.14792C > G and the already known m.14459G > A resulting in p.His16Asp change in cytochrome b (MTCYB) and p.Ala72Val substitution in ND6 subunit, respectively. The m.14459G > A was heteroplasmic in the mother's blood-derived DNA.

Conclusions: The m.14459G > A might lead to LS, complicated LS or Leber Optic Hereditary Neuropathy. A comprehensive re-evaluation of previously described 14459G > A-mutated patients does not explain this large clinical heterogeneity.
\end{abstract}

Keywords: Leigh Syndrome, mitochondrial DNA, LHON, MT-ND6, MT-CYB, mitochondrial Complex I

\section{Background}

Leigh Syndrome (LS, OMIM 256000) is a subacute necrotizing encephalomyelopathy characterized by bilateral symmetrical necrotic lesions of gray matter nuclei in the basal ganglia, diencephalon, cerebellum or brainstem. The onset is usually in early infancy and patients manifest an heterogeneous set of symptoms, such as regression or psychomotor delay, weakness, hypotonia, truncal ataxia, intention tremor associated with lactic acidosis in the blood, cerebrospinal fluid or urine. The prognosis is poor and, in most cases, patients die before

\footnotetext{
* Correspondence: giacomo.comi@unimi.it

'Centro Dino Ferrari, Department of Neurological Sciences, University of Milan, Foundation IRCCS Ca' Granda Ospedale Maggiore Policlinico, via Francesco Sforza 35, 20122 Milan, Italy

Full list of author information is available at the end of the article
}

age of 5 years. It is the most frequent cause of inherited mitochondrial disorder in infancy $(1: 40,000)$ [1].

LS inheritance is complex since patients may present mutations in mitochondrial DNA (mtDNA) or in nuclear genes, which predominantly encode for proteins involved in respiratory chain structure and assembly or in coenzyme Q10 biogenesis [2]. Among maternally inherited forms, most of the mutations lay within genes encoding Complex I (ND1-6) and V (ATP6, ATP8) mitochondrial subunits [3].

Here we report the clinical, biochemical and molecular features of a pediatric patient affected by Leigh Syndrome associated with the mitochondrial DNA mutation m.14459G > A within MT-ND6 gene. 


\section{Case Presentation Case report}

The proband is a 15-month-old female patient born from healthy nonconsanguineous Italian parents after a regular pregnancy and delivery. Feeding problems and gastroesophageal reflux were noted from the first weeks of life. At the age of 3 months, after the first vaccination, she started to present dystonic postures of the trunk initially misdiagnosed as related to gastroesophageal reflux. At the age of 5 months, after the second vaccination, she started to present irritability, inconsolable crying, psychomotor regression and generalized seizures. She was treated with endorectal diazepam, and after that she had no others seizure episodes. At 7 months of age, after an intercurrent viral illness, she was referred to our department in Pavia. The clinical picture was characterized by psychomotor delay, dystonic-dyskinetic tetraparesis, startle reaction to sudden acoustic stimuli, episodic central apneas. Plasma amino acids revealed high level of alanine, valine, isoleucine and lysine with abnormal ratio alanine:lysine (3.7, range of normality $=1.5-2.5$ ). Urinary organic acids revealed high level of lactic, pyruvic, fumaric and 3-ketoglutaric acids. High levels of lactic and pyruvic acids were also demonstrated both in plasma and CSF. MRI showed bilateral symmetric hyperintense lesions on T2-weighted images in the basal ganglia, thalami and ventral mesencephalum (Figure 1A). Brain CT scan didn't show calcification. Fundus oculi showed retinal depigmentation; assessment of VEPs revealed evidence of a conduction delay and ERG showed retinal involvement. Auditory brainstem responses, ECG and echocardiogram were normal.

A treatment with riboflavine $50 \mathrm{mg} /$ day, thiamine 150 $\mathrm{mg} /$ day $300 \mathrm{mg}: 1 / 2 \mathrm{cp}$, carnitine $100 \mathrm{mg} / \mathrm{kg} /$ day was started.

At 8 months of age she started to present external ophthalmoplegia and absence of pupillary reaction. Hereafter the clinical picture remained stable.

A muscle tissue biopsy was normal at the morphological and histochemical studies, with the exception of a mild increase in acid phosphatase staining at subsarcolemmal level in a few fibres.

Family history for neurological disorders was negative. General clinical assessment of her mother was normal.
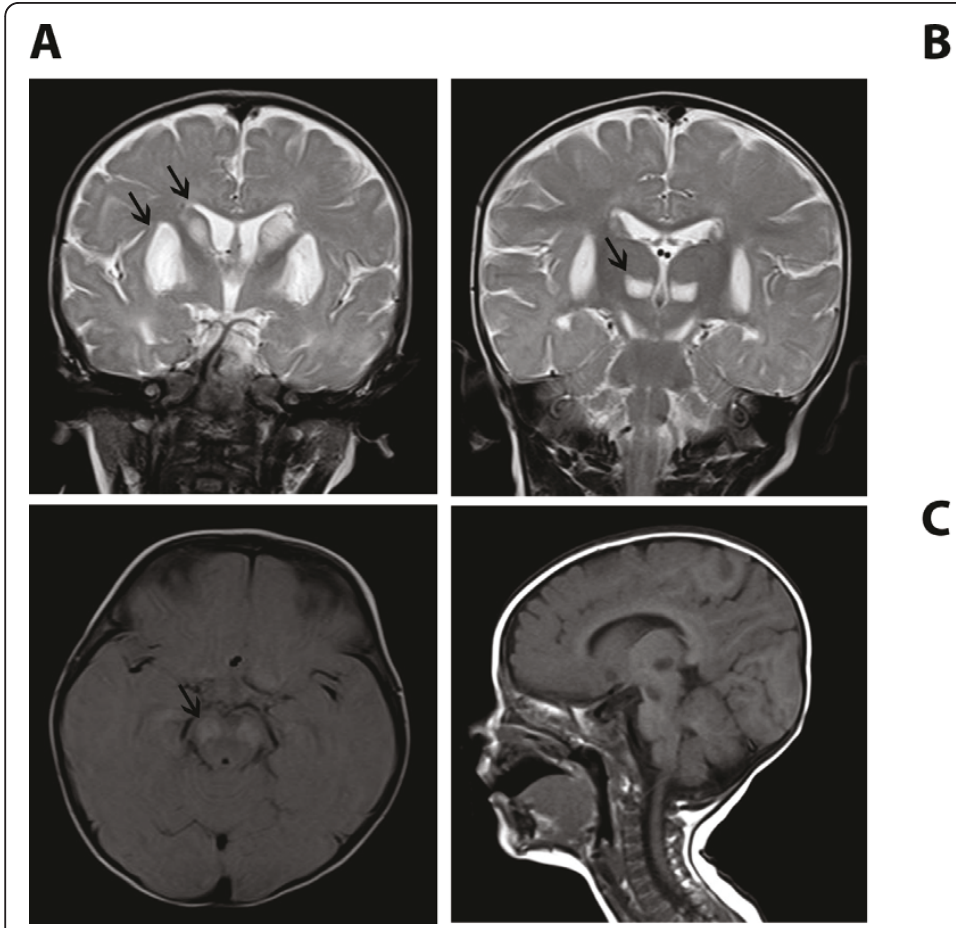

Figure 1 Neuroradiological and molecular features in our proband. A. Brain MRI showed bilateral symmetric hyperintense lesions on T2weighted images in the head of caudate, putamen (top left), thalami (top right) and ventral mesencephalum (bottom left); these lesions were hypointense in T1-weighted images (bottom right). B. PCR-RFLP analysis of m.14459G > A mutation. The transition m.14459G > A creates a restriction site for endonuclease Maelll in mutated amplicons obtained using a modified primer set previously described (FOR14430*-RC14710) producing two fragments of 251 and 29 base pairs (the latter is not visible on the agarose gel) while wild type molecules remain uncut. C. PCRRFLP analysis of $\mathrm{m} .14792 \mathrm{C}>\mathrm{G}$ variant. The variant $\mathrm{m} .14792 \mathrm{C}>\mathrm{G}$ is recognized by restriction endonuclease Hinfl which cuts mutated PCRamplified fragments (encompassing 14400-14963 nucleotides) producing molecules of 392 and 171 base pairs. Control samples are from healthy unrelated independent subjects. 


\section{Results}

Spectrophotometric determination of the activity of mitochondrial Complex I in muscle showed a residual activity of $36 \%$ compared to controls $(\mathrm{CI} / \mathrm{CS}=5.9 \mathrm{nM} /$ $\mathrm{min} / \mathrm{mg}$ protein, control values $=16.5 \pm 2.6$ normalized to citrate synthase, $\mathrm{CS}$ ).

Large-scale mtDNA rearrangements and mtDNA depletion was excluded by Southern Blot and quantitative PCR assays on muscle-derived DNA.

Direct sequencing of muscle-derived mtDNA revealed the presence of two apparently homoplasmic variants: the novel m.14792C > G and the already known m.14459G > A resulting in p.His16Asp change in cytochrome b (MT-CYB) and p.Ala72Val substitution in ND6 subunit, respectively. Their presence was confirmed by specific PCR-RFLP assays. The sequence also showed that the patient belongs to the mitochondrial haplogroup $\mathrm{H} 2 \mathrm{a} 2$, consisting to European ethnic groups.

The mother's mtDNA was homoplasmic for MT-CYB variant and heteroplasmic for the MT-ND6 mutation with a mutational load estimated less than $2 \%$ by PCRRFLP analysis (Figure 1B and Figure 1C).

\section{Conclusions}

The variant m.14459G > A has been so far reported in six patients affected by Leber's hereditary optic neuropathy (LHON), in seven probands mainly showing dystonia and in four LS/Leigh-like Syndrome (LLS) patients [4-9]. Clinical, biochemical and genetical features of the aforementioned probands are summarized in Table 1. Phenotypic manifestations of this variant are expressed in both sexes with approximately equal frequency. However, the reason for the striking difference in the clinical outcome of the m.14459G > A mutation between patients is unknown.

Patients so far described belong to different ethnic groups and they likely present different mtDNA haplogroups although a precise definition of the haplotypes is available in few subjects. The available haplotypes include H, T (West Eurasia and Middle East) and D (East Asia and Americas). This fact suggests that the mutation arose independently several times in a period of time relatively recent.

Although mitochondrial haplogroups could influence the phenotypic expression of LHON and LS associated variant [10-12], no evidence has been produced for m.14459G > A and haplotype H2a2 disclosed in our patient.

Clinical manifestations of m.14459G > A transition seem to mainly affect central nervous system and skeletal muscle. CNS, brainstem and optic nerve are often compromised but some patients may present more systemic manifestations. Dystonia is the most occurring feature described alone or associated to LS/LLS.
The transition $\mathrm{m} .14459 \mathrm{G}>\mathrm{A}$ is considered a rare causative mutation for LHON [13]. Our proband had delayed VEP, together with signs of retinal involvement, probably reflecting multiple sites of affection along the optic pathways. The involvement of visual pathway in 14459G > A-mutated patients is generally a later event in contrast to dystonia that develops in the early childhood. To date the co-existence of LLS and LHON has been clearly described in a single proband [7].

Laboratory findings are inconsistent and the elevation of lactate level in blood and/or CSF found in some LS patients, as wells as in our proband, is not peculiar to this molecular defect.

Neuroradiological examinations, when performed, showed lesions in brainstem and basal ganglia in LS and dystonia patients. A positive result at MRI investigation could address the diagnosis of dystonia or LS although exceptions to this correlation have been reported.

Muscle biopsy did not show striking signs of mitochondrial impairment: in our proband no ragged-red or cytochrome $c$ oxidase-negative fibers were observed. Minor changes such as mild variations in fiber size and accumulation of subsarcolemmal mitochondria have been reported in a few patients $[5,7,8]$. As in the case of other mutations affecting structure or assembly of Complex I, histological analysis may not prove helpful in uncovering mitochondrial pathology.

Spectrophotometric analysis of the activity of respiratory chain complexes has been reported in early onset patients who underwent muscle biopsy. Residual activity of Complex I ranges from 3 to $76 \%$ compared to control. Secondary defects have been also observed in Complex III [5]. Fibroblasts culture established from two LS patients confirmed a severe reduction of enzymatic activity [6]. In our patient we observed a strong reduction of Complex I activity in skeletal muscle, compatible with the marked hypotonia observed.

Analysis of transmitochondrial cybrids previously confirmed that m.14459G > A leads to the impairment of Complex I activity [14].

No obvious correlation between mutant load and clinical features is observed. High levels of heteroplasmy in blood have been described in LHON, dystonia and LS patients. In the first report [4], even an asymptomatic subject had $99 \%$ of mutant mtDNA in lymphoblasts but it was suggested that it could be due to an artifact of transformation and cell culture [6]. Tissues derived from LS patients generally present a virtually homoplasmic state [6], as in the case of our proband. Conversely, mutant DNA detected in blood from LHON patients differs widely, with heteroplasmy ranging from 18 to $99 \%$.

The pathological manifestation of the m.14459G > A mutation is thought to be highly tissue-specific, 
Table 1 Clinical, biochemical and molecular features of m.14459G > A mutated patients

\begin{tabular}{|c|c|c|c|c|c|c|c|c|c|c|}
\hline Reference & Patient & Sex & Ethnic group & Age & $\begin{array}{c}\text { Age } \\
\text { of } \\
\text { Onset }\end{array}$ & Phenotype & Clinical features & Neuroradiology & $\begin{array}{l}\text { Residual } \mathrm{Cl} \\
\text { activity }\end{array}$ & $\begin{array}{c}\text { m.14459G } \\
>A \\
\text { Mutational } \\
\text { load (\%) }\end{array}$ \\
\hline $\begin{array}{l}\text { Current } \\
\text { Study }\end{array}$ & A & $\mathrm{F}$ & $\begin{array}{l}\text { Caucasian } \\
\text { Haplogroup } \\
\text { H2a2 }\end{array}$ & $18 \mathrm{~m}$ & $2 m$ & $\begin{array}{c}\mathrm{LS} \\
+ \text { +Dystonia }\end{array}$ & $\begin{array}{l}\text { Psycomotor delay, } \\
\text { hypotonia, } \\
\text { dystonia. }\end{array}$ & $\begin{array}{l}\text { MRI: lesions in the } \\
\text { basal ganglia and } \\
\text { mesencephalum. }\end{array}$ & $\begin{array}{c}36 \% \\
\text { (muscle) }\end{array}$ & $\begin{array}{c}>99 \\
\text { (muscle) } \\
>99 \text { (blood) }\end{array}$ \\
\hline $\begin{array}{l}\text { Shoffner } \\
\text { et al. [5] }\end{array}$ & $\begin{array}{c}\text { B1-1 } \\
\text { (proband) }\end{array}$ & $F$ & $\begin{array}{l}\text { African- } \\
\text { American }\end{array}$ & $19 y$ & $3 \mathrm{~m}$ & LHON & $\begin{array}{c}\text { Loss of bilateral } \\
\text { vision, optic } \\
\text { atrophy }\end{array}$ & $\begin{array}{c}\text { MRI: lesions in } \\
\text { caudate nucleus } \\
\text { and right putamen }\end{array}$ & $3 \%$ (muscle) & $>99$ \\
\hline $\begin{array}{l}\text { Shoffner } \\
\text { et al. [5] }\end{array}$ & $\begin{array}{c}\text { B1-2 } \\
\text { (proband's } \\
\text { mother) }\end{array}$ & $\mathrm{F}$ & $\begin{array}{l}\text { African- } \\
\text { American }\end{array}$ & $42 y$ & $42 y$ & LHON & $\begin{array}{l}\text { Loss of bilateral } \\
\text { vision, optic } \\
\text { atrophy }\end{array}$ & $\mathrm{NP}$ & NP & 50 \\
\hline $\begin{array}{l}\text { Shoffner } \\
\text { et al. [5] }\end{array}$ & B2 & $F$ & Caucasian & $13 y$ & $3 y$ & Dystonia & $\begin{array}{c}\text { Dysarthria, } \\
\text { dystonia, } \\
\text { quadriparesis }\end{array}$ & $\begin{array}{c}\text { CT: bilateral } \\
\text { hipodensity in the } \\
\text { putamina. MRI: } \\
\text { bilateral lesions in } \\
\text { putamen and } \\
\text { caudate. }\end{array}$ & NP & 50 \\
\hline $\begin{array}{l}\text { Funalot } \\
\text { et al. [7] }\end{array}$ & $\mathrm{C} 2$ & $M$ & $\begin{array}{c}\text { Caucasian } \\
\text { Haplogroup T }\end{array}$ & $\begin{array}{c}\text { +32y } \\
\text { suicide }\end{array}$ & $18 y$ & $\mathrm{LLS}+\mathrm{LHON}$ & $\begin{array}{c}\text { Bilateral visual } \\
\text { failure, hearing } \\
\text { loss, ataxia, } \\
\text { extrapiramidal } \\
\text { signs }\end{array}$ & $\begin{array}{c}\text { MRI: hyperintensity } \\
\text { in dorsal midbrain; } \\
\text { bilateral lesions in } \\
\text { the third ventricle } \\
\text { walls. }\end{array}$ & NP & 40 \\
\hline $\begin{array}{l}\text { Gropman } \\
\text { et al. [9] }\end{array}$ & $\begin{array}{c}\text { D1 } \\
\text { (proband) }\end{array}$ & $\mathrm{F}$ & Hispanic & $4 y$ & $3 y$ & Dystonia & $\begin{array}{c}\text { Anarthria, dystonia, } \\
\text { spasticity, } \\
\text { encefalopathy, } \\
\text { neurofibromatosis }\end{array}$ & $\begin{array}{c}\text { MRI: bilateral } \\
\text { hyperintensities of } \\
\text { the putamen. MRS: } \\
\text { elevated lactate. }\end{array}$ & $\begin{array}{c}76 \% \\
\text { (muscle) }\end{array}$ & $>99$ \\
\hline $\begin{array}{l}\text { Gropman } \\
\text { et al. [9] }\end{array}$ & $\begin{array}{c}\text { D1-2 } \\
\text { (proband's } \\
\text { mother) }\end{array}$ & $\mathrm{F}$ & Hispanic & $35 y$ & $34 y$ & & $\begin{array}{l}\text { neurofibromatosis, } \\
\text { muscle weakness }\end{array}$ & $\begin{array}{c}\text { MRl: bitemporal } \\
\text { signal abnormalities }\end{array}$ & NP & $>99$ \\
\hline $\begin{array}{l}\text { Gropman } \\
\text { et al. [9] }\end{array}$ & $\begin{array}{c}\text { D1-3 } \\
\text { (proband's } \\
\text { brother) }\end{array}$ & $M$ & Hispanic & $7 y$ & $2 y$ & Dystonia & $\begin{array}{c}\text { neurofibromatosis, } \\
\text { hemiparesis, } \\
\text { cognitive delay }\end{array}$ & $\begin{array}{c}\text { MRI: right sided } \\
\text { putaminal infarcts, } \\
\text { thickened corpus } \\
\text { callosum }\end{array}$ & NP & $>99$ \\
\hline $\begin{array}{l}\text { Gropman } \\
\text { et al. [9] }\end{array}$ & $\begin{array}{l}\text { D1-3 } \\
\text { (maternal } \\
\text { cousin) }\end{array}$ & $\mathrm{F}$ & Hispanic & $5 y$ & $5 y$ & - & Hemiparesis & $\begin{array}{c}\text { MRI: bilateral } \\
\text { putaminal infarcts } \\
\text { MRS: elevated } \\
\text { lactate }\end{array}$ & NP & $>99$ \\
\hline $\begin{array}{c}\text { Kirby et al. } \\
{[6]}\end{array}$ & E1-1 & $F$ & $?$ & $+7 y$ & $9 \mathrm{~m}$ & LS & $\begin{array}{c}\text { Motor delay, } \\
\text { hypotonia, seizure, } \\
\text { dystonia. }\end{array}$ & $\begin{array}{l}\mathrm{CT} \text { : bilateral low } \\
\text { density lesions of } \\
\text { the basal ganglia }\end{array}$ & $\begin{array}{c}25 \% \\
\text { (fibroblasts) }\end{array}$ & $\begin{array}{c}97 \\
\text { (fibroblasts) }\end{array}$ \\
\hline $\begin{array}{c}\text { Kirby et al. } \\
\text { [6] }\end{array}$ & $\begin{array}{c}\text { E1-2 } \\
\text { (proband's } \\
\text { brother) }\end{array}$ & M & $?$ & $\dagger 10 \mathrm{~m}$ & $3 \mathrm{~m}$ & LS & $\begin{array}{c}\text { Hypotonia, } \\
\text { neurological and } \\
\text { developmental } \\
\text { regression, seizure. } \\
\text { Metabolic acidosis. }\end{array}$ & - & $\begin{array}{l}6 \% \text { (muscle) } \\
46 \% \text { (liver) }\end{array}$ & $\begin{array}{l}97 \text { (muscle, } \\
\text { liver) }\end{array}$ \\
\hline $\begin{array}{c}\text { Kirby et al. } \\
\text { [6] }\end{array}$ & E2 & $\mathrm{F}$ & $?$ & $+8 \mathrm{~m}$ & $6 \mathrm{~m}$ & LS & $\begin{array}{c}\text { Developmental } \\
\text { delay, athetosis, } \\
\text { hypotonia. }\end{array}$ & $\begin{array}{c}\text { MRI: cerebral } \\
\text { atrophy, } \\
\text { involvement of } \\
\text { basal ganglia and } \\
\text { medial thalamic } \\
\text { nuclei. }\end{array}$ & $\begin{array}{c}15 \% \\
\text { (fibroblasts) } \\
16 \% \\
\text { (muscle) } \\
37 \% \text { (liver) }\end{array}$ & $\begin{array}{l}97 \text { (muscle, } \\
\text { liver) }\end{array}$ \\
\hline Jun et al. [4] & $\begin{array}{c}\text { G1-1 } \\
\text { (proband) }\end{array}$ & $\mathrm{F}$ & $\begin{array}{c}\text { Hispanic } \\
\text { (Native } \\
\text { American). } \\
\text { Haplogroup D }\end{array}$ & $10 y$ & $2 y$ & Dystonia & $\begin{array}{l}\text { Dystonia, } \\
\text { corticospinal tract } \\
\text { dysfunction, } \\
\text { dysarthria. }\end{array}$ & $\begin{array}{c}\text { CT: bilateral low } \\
\text { density lesions in } \\
\text { putamen } \\
\text { progressing to the } \\
\text { caudate }\end{array}$ & - & 99 (blood) \\
\hline Jun et al. [4] & $\begin{array}{c}\text { G1-2 } \\
\text { (proband's } \\
\text { brother) }\end{array}$ & M & $\begin{array}{c}\text { Hispanic } \\
\text { (Native } \\
\text { American). } \\
\text { Haplogroup D }\end{array}$ & $13 y$ & $13 y$ & Dystonia & $\begin{array}{c}\text { Dystonia, } \\
\text { intellectual } \\
\text { impairmeint. }\end{array}$ & $\mathrm{NP}$ & NP & 99 (blood) \\
\hline
\end{tabular}


Table 1 Clinical, biochemical and molecular features of m.14459G > A mutated patients (Continued)

\begin{tabular}{|c|c|c|c|c|c|c|c|c|c|c|}
\hline Jun et al. [4] & $\begin{array}{l}\text { G1-3 } \\
\text { (proband's } \\
\text { mother) }\end{array}$ & $\mathrm{F}$ & $\begin{array}{c}\text { Hispanic } \\
\text { (Native } \\
\text { American). } \\
\text { Haplogroup D }\end{array}$ & $32 y$ & $32 y$ & LHON & $\begin{array}{l}\text { Bilateral optic } \\
\text { atrophy. }\end{array}$ & NP & NP & 73 (blood) \\
\hline Jun et al. [4] & $\begin{array}{l}\text { G1-4 } \\
\text { (maternal } \\
\text { cousin) }\end{array}$ & $M$ & $\begin{array}{c}\text { Hispanic } \\
\text { (Native } \\
\text { American). } \\
\text { Haplogroup D }\end{array}$ & $?$ & $?$ & LHON & - & NP & NP & 99 (blood) \\
\hline Jun et al. [4] & $\begin{array}{l}\text { G1-5 } \\
\text { (maternal } \\
\text { relative) }\end{array}$ & $M$ & $\begin{array}{c}\text { Hispanic } \\
\text { (Native } \\
\text { American). } \\
\text { Haplogroup D }\end{array}$ & $?$ & $5 y$ & Dystonia & Dystonia & $\begin{array}{l}\text { CT: abnormal basal } \\
\text { ganglial lucencies }\end{array}$ & NP & 99 (blood) \\
\hline $\begin{array}{l}\text { Tarnopolsky } \\
\text { et al. [8] }\end{array}$ & $\begin{array}{c}\text { E1-1 } \\
\text { (proband) }\end{array}$ & $\mathrm{F}$ & Caucasian & $45 y$ & $8 y$ & Dystonia & Dystonia & $\begin{array}{l}\text { MRI: hiperintensities } \\
\text { signal in putamen }\end{array}$ & $\mathrm{N}$ & 34 (blood) \\
\hline $\begin{array}{l}\text { Tarnopolsky } \\
\text { et al. [8] }\end{array}$ & $\begin{array}{l}\text { E1-2 } \\
\text { (proband's } \\
\text { brother) }\end{array}$ & $M$ & Caucasian & $49 y$ & $19 y$ & LHON & $\begin{array}{l}\text { Visual loss, hearing } \\
\text { loss }\end{array}$ & NP & NP & 18 (blood) \\
\hline $\begin{array}{l}\text { Tarnopolsky } \\
\text { et al. [8] }\end{array}$ & $\begin{array}{l}\text { E1-3 } \\
\text { (proband's } \\
\text { brother) }\end{array}$ & $M$ & Caucasian & $56 y$ & $?$ & - & $\begin{array}{l}\text { Visual changes, } \\
\text { hearing loss, } \\
\text { muscle weakness. }\end{array}$ & NP & NP & 21 (blood) \\
\hline $\begin{array}{l}\text { Tarnopolsky } \\
\text { et al. [8] }\end{array}$ & $\begin{array}{l}\text { E1-4 } \\
\text { (proband's } \\
\text { mother) }\end{array}$ & $\mathrm{F}$ & Caucasian & $78 y$ & $76 y$ & - & Stroke episodes. & $\begin{array}{l}\text { CT: hipodensity in } \\
\text { right frontal } \\
\text { periventricular } \\
\text { region }\end{array}$ & NP & 4 (blood) \\
\hline $\begin{array}{l}\text { Tarnopolsky } \\
\text { et al. [8] }\end{array}$ & E2 & $M$ & Caucasian & $17 y$ & $16 y$ & LHON & $\begin{array}{c}\text { Optic nerve pallor, } \\
\text { visual loss. }\end{array}$ & MRI: normal & NP & 26 (blood) \\
\hline
\end{tabular}

NP: not performed; Cl: Complex I,\% values refer to activity compared to controls.

depending also on the levels of heteroplasmy present in each organ or tissue involved and this fact could explain the different clinical phenotypes [5]. The existence of secondary mtDNA variants able to modify the disease presentation of a primary mutation has been suggested before $[15,16]$. In our proband, we observed a novel homoplasmic variant m.14792C > G, which was absent in 162 Italian healthy controls. The proband's mother was homoplasmic for this nucleotide change (and heteroplasmic for the m.14459G > A mutation). Since her general clinical assessment was normal, the MT-CYB variant is unlikely to have a pathogenic significance.

Unfortunately, no cytochrome b region sequence data are available for the previously reported 14459G $>$ A-mutated subjects. Moreover, some of the reported probands, who share the same maternal lineage, present very heterogeneous symptoms $[8,9]$. These elements suggest that other factors, external to mitochondrial DNA, are relevant to explain the clinical heterogeneity of m.14459 mutation, making the contribution to disease of the novel m.14792C > G variant purely speculative. The assessment of respiratory chain activity in transmitochondrial cybrids derived from the proband and her mother would be helpful to settle this point but this analysis is unfortunately not feasible, due to the unavailability of primary cell cultures.

\section{Consent}

Written informed consent was obtained from the patient's parents for publication of this case report and any accompanying images. A copy of the written consent is available for review by the Editor in Chief of this journal.

\section{List of abbreviations}

LS: Leigh Syndrome; mtDNA: mitochondrial DNA; PCR-RFLP: polymerase chain reaction - restriction site length polymorphism; LHON: Leber's hereditary optic neuropathy; CNS: central nervous system; CSF: cerebrospinal fluid.

\section{Acknowledgements}

Gratitude has to be expressed to the patient's family for participating in this research. We wish to thank especially the 'Associazione Amici del Centro Dino Ferrari' for their support. The work was partially supported by the Italian Telethon grant GUP09004 "Construction of a database for a nationwide Italian collaborative network of mitochondrial diseases".

\section{Author details}

${ }^{1}$ Centro Dino Ferrari, Department of Neurological Sciences, University of Milan, Foundation IRCCS Ca' Granda Ospedale Maggiore Policlinico, via Francesco Sforza 35, 20122 Milan, Italy. ${ }^{2}$ Foundation IRCCS Istituto Neurologico C. Mondino, Via Mondino 2, 27100 Pavia, Italy. ${ }^{3}$ Epilepsy Center, Department of Child Neuropsychiatry, C Poma Hospital, Strada Lago Paiolo 10, 46100 Mantova, Italy.

\section{Authors' contributions}

DR and AC participated the molecular genetic studies and drafted the manuscript. $A B, F F$ and MR partecipated the molecular and biochemical studies. AC, DT, SO and MC carried out the clinical evaluation of the patient and wrote the patient case. SC and PC carried out the neurological studies. 
MS and MM carried out the histological analysis. GPC, AB, PV conceived of the study, partecipated in its design and coordination and helped to draft the manuscript. All authors read and approved the final manuscript.

\section{Competing interests}

The authors declare that they have no competing interests.

Received: 7 March 2011 Accepted: 12 July 2011 Published: 12 July 2011

\section{References}

1. Rahman S, Blok RB, Dahl HH, Leigh syndrome, et al: Clinical features and biochemical and DNA abnormalities. Ann Neurol 1996, 39:343-51.

2. Tucker EJ, Compton AG, Thorburn DR: Recent advances in the genetics of mitochondrial encephalopathies. Curr Neurol Neurosci Rep 2010, 10:277-85.

3. Wong LJ: Pathogenic mitochondrial DNA mutations in protein-coding genes. Muscle Nerve 2007, 36:279-93.

4. Jun $A S$, Brown MD, Wallace DC: A mitochondrial DNA mutation at nucleotide pair 14459 of the NADH dehydrogenase subunit 6 gene associated with maternally inherited Leber hereditary optic neuropathy and dystonia. Proc Natl Acad Sci USA 1994, 91:6206-10.

5. Shoffner JM, Brown MD, Stugard C, Jun AS, Pollock S, Haas RH, Kaufman A, Koontz D, Kim Y, Graham JR, et al: Leber's hereditary optic neuropathy plus dystonia is caused by a mitochondrial DNA point mutation. Ann Neurol 1995, 38:163-9.

6. Kirby DM, Kahler SG, Freckmann ML, Reddihough D, Thorburn DR: Leigh disease caused by the mitochondrial DNA G14459A mutation in unrelated families. Ann Neurol 2000, 48:102-4.

7. Funalot B, Reynier P, Vighetto A, Ranoux D, Bonnefont JP, Godinot C, Malthièry $Y$, Mas JL: Leigh-like encephalopathy complicating Leber's hereditary optic neuropathy. Ann Neurol 2002, 52:374-7.

8. Tarnopolsky MA, Baker SK, Myint T, Maxner CE, Robitaille J, Robinson BH: Clinical variability in maternally inherited leber hereditary optic neuropathy with the G14459A mutation. Am J Med Genet A 2004, 124:372-6.

9. Gropman A, Chen TJ, Perng CL, Krasnewich D, Chernoff E, Tifft C, Wong L: Variable clinical manifestation of homoplasmic G14459A mitochondrial DNA mutation. Am J Med Genet A 2004, 124:377-82.

10. Torroni A, Petrozzi M, D'Urbano L, Sellitto D, Zeviani M, Carrara F, Carducci C, Leuzzi V, Carelli V, Barboni P, De Negri A, Scozzari R: Haplotype and phylogenetic analyses suggest that one European-specific mtDNA background plays a role in the expression of Leber hereditary optic neuropathy by increasing the penetrance of the primary mutations 11778 and 14484. Am J Hum Genet 1997, 60:1107-21.

11. Hudson G, Carelli V, Spruijt L, Gerards M, Mowbray C, Achilli A, Pyle A, Elson J, Howell N, La Morgia C, Valentino ML, Huoponen K, Savontaus ML, Nikoskelainen E, Sadun AA, Salomao SR, Belfort R Jr, Griffiths P, Man PY, de Coo RF, Horvath R, Zeviani M, Smeets HJ, Torroni A, Chinnery PF: Clinical expression of Leber hereditary optic neuropathy is affected by the mitochondrial DNA-haplogroup background. Am J Hum Genet 2007, 81:228-33.

12. D'Aurelio M, Vives-Bauza C, Davidson MM, Manfredi G: Mitochondrial DNA background modifies the bioenergetics of NARP/MILS ATP6 mutant cells. Hum Mol Genet 2010, 19:374-86.

13. Yu-Wai-Man P, Griffiths PG, Hudson G, Chinnery PF: Inherited mitochondrial optic neuropathies. J Med Genet 2009, 46:145-58.

14. Jun AS, Trounce IA, Brown MD, Shoffner JM, Wallace DC: Use of transmitochondrial cybrids to assign a complex I defect to the mitochondrial DNA-encoded NADH dehydrogenase subunit 6 gene mutation at nucleotide pair 14459 that causes Leber hereditary optic neuropathy and dystonia. Mol Cell Biol 1996, 16:771-7.

15. Johns DR, Smith KH, Savino PJ, Miller NR: Leber's hereditary optic neuropathy. Clinical manifestations of the 15257 mutation. Ophthalmology 1993, 100:981-6.

16. Lodi R, Montagna P, Cortelli P, lotti S, Cevoli S, Carelli V, Barbiroli B: 'Secondary' 4216/ND1 and 13708/ND5 Leber's hereditary optic neuropathy mitochondrial DNA mutations do not further impair in vivo mitochondrial oxidative metabolism when associated with the 11778/ ND4 mitochondrial DNA mutation. Brain 2000, 123:1896-902.

\section{Pre-publication history}

The pre-publication history for this paper can be accessed here: http://www.biomedcentral.com/1471-2377/11/85/prepub doi:10.1186/1471-2377-11-85

Cite this article as: Ronchi et al: Clinical and molecular features of an infant patient affected by Leigh Disease associated to $\mathrm{m} .14459 \mathrm{G}>\mathrm{A}$ mitochondrial DNA mutation: a case report. BMC Neurology 2011 11:85.

\section{Submit your next manuscript to BioMed Central and take full advantage of:}

- Convenient online submission

- Thorough peer review

- No space constraints or color figure charges

- Immediate publication on acceptance

- Inclusion in PubMed, CAS, Scopus and Google Scholar

- Research which is freely available for redistribution

Submit your manuscript at www.biomedcentral.com/submit
Ciomed Central 